\title{
ALGUNS PONTOS COINCIDENTES ENTRE O POSITIVISMO DE AUGUSTE COMTE E O PENSAMENTO DE DARIO VELLOZO NA REVISTA O CENÁCULO
}

\section{SOME COINCIDING POINTS BETWEEN AUGUSTE COMTE'S POSITIVISM AND DARIO VELOZO'S THOUGHTS IN O CENÁCULO MAGAZINE}

\author{
Recebido: 14/05/2020 | Aprovado: 18/06/2020 | Publicado: 10/07/2020 \\ DOI: https://doi.org/10.18817/rlj.v4i1.2306
}

Isabela Melim Borges ${ }^{1}$

\begin{abstract}
Resumo: A virada do século XIX para o XX foi um momento profícuo no campo da intelectualidade brasileira, mais precisamente na área literária que se via impregnada de muitas filosofias importadas. Majoritariamente o Positivismo de Auguste Comte ocupava esse espaço. Foi com essa filosofia que Dario Vellozo dialogou, sobretudo na sua prosa. Para além do ocultismo presente na sua vasta obra, Vellozo manteve o Positivismo em alto grau nas suas produções. O presente artigo discute alguns desses diálogos, evidenciando a filosofia francesa nos principais escritos de Dario Vellozo, na revista $O$ Cenáculo. Este texto propõe iluminar o mosaico que era o intelectual fundador do Instituto NeoPitagórico.
\end{abstract}

Palavras-chave: Positivismo. Dario Vellozo. O Cenáculo.

\begin{abstract}
The turn of the nineteenth century to the twentieth was a fruitful moment in the field of Brazilian intellectuality, more precisely in the literary area, that was impregnated with many imported philosophies. Mostly Auguste Comte's Positivism occupied this space. It was with this philosophy that Dario Vellozo spoke, mainly in his prose. In addition to the occultism, present in his vast work, Vellozo maintained Positivism in a high degree in his productions. This paper discusses some of these dialogues, showing the French philosophy in the main thoughts of Dario Vellozo, in the magazine O Cenáculo. This paper's propose is to illuminate the mosaic that was the intellectual founder of the Neo-Pythagorean Institute.
\end{abstract}

Keywords: Positivism. Dario Vellozo. O Cenáculo.

Dario Persiano de Castro Vellozo nasceu no bairro do São Cristóvão, no Rio de Janeiro, em 26 de novembro de 1869. É o filho mais velho de Cyro Persiano de Almeida Vellozo e de Zulmira Mariana de Castro Vellozo, que morreu em 1879, quando Dario tinha 10 anos de idade. Em 1885, mudou-se para Curitiba com seu pai e seu

\footnotetext{
${ }^{1}$ Doutoranda em Literatura Brasileira/UFSC. Mestre em Literatura Brasileira/UFSC, assim como o Bacharelado e a Licenciatura. Tem experiência na área de Letras, atuando, principalmente, nos seguintes temas: poesia, história literária, literatura brasileira, teoria literária, história das ideias, ensino/aprendizagem da literatura com uso de ferramentas digitais (DLNotes e Aoidos). Integrante do Núcleo de Pesquisa em informática, literatura e linguística (NuPILL), editora-chefe da revista Texto Digital. E-mail: isamelim74@gmail.com
} 
irmão. Nesse mesmo ano, foi tipógrafo do jornal Dezenove de Dezembro e, entre 1886 e 1889, de acordo com Tarcisa Bega, ele estudou no Partenon Paranaense e, em seguida, no Ginásio Paranaense (2012, p. 214). Foi nessa época, trabalhando naquele jornal, que conheceu Silveira Netto, Nestor Victor, Emílio de Menezes, Júlio Pernetta e outros mais. Em 1894, na Revista do Club Coritibano, escreve:

\begin{abstract}
Conhecemo-nos em agosto de 1885, na oficina do Dezenove de Dezembro, onde João Lycio também trabalhava como compositor-tipógrafo [...]. Por esse tempo não rabiscávamos papel; idolatrávamos o Casemiro de Abreu, o Castro Alves, o Junqueira Freire e o Álvares de Azevedo. Reuníamo-nos, em nossa casa, e, com o coração ciliciado pelo infortúnio e brios dos patronos, declamávamos liturgicamente o Noite na Taverna, os Escravos, ou alguma poesia das Primaveras ou dos cantos dos Claustros. Não tínhamos orientação literária. Deleitava-nos palestrar esses divinos inspirados que nos falavam à alma, derramando por sobre o nosso coração, precocemente envolto nas delicadíssimas teias dos primeiros sonhos, a fúlgida âmbula fatídica dos amargurosos tóxicos cetisantes e elucidativos. Bons rapazes, como nós entusiastas e confiosos, completavam o cenáculo. Data, de então, o superno culto de amizade que reciprocamente nos votamos (pág. 1 e 2).
\end{abstract}

De acordo com Valfrido Pilotto, o pai de Dario foi presidente do Club Coritibano entre os anos de 1889 e 1891, onde, em 1890, fundou a Revista do Club (1990, p. 37). Segundo Maria Tarcisa Bega, a Revista do Club Coritibano era um dos principais veículos culturais da elite local, voltada aos associados do clube. "Publicou não somente os autores locais, como em suas páginas foram desenvolvidas algumas teorias sobre higienismo, civilização, dando conhecimento público aos escritos positivistas e filosóficos do século XIX (2013, p. 97 - 98). Ainda, em 1889, Vellozo publicou seu primeiro livro de versos, Efêmeras, e sobre ele diz: "Ao tempo das Efêmeras... Tinha eu vinte e um anos. Em doze signos, fora caminhar alentado: Andavam comigo os "Obeliscos hieroglifados» e os monumentos egípcios; andavam comigo a Recordação e a Saudade. Já então me atraía o fulgor dos astros longínquos! " (VELLOZO, 1969, v. I, p. 404). Ou seja, já nas Efêmeras está presente indícios de sua verve esotérica, mesmo que se manifeste apenas no vocabulário.

Para além da Revista do Club Coritibano, Dario Vellozo manteve uma constante divulgação das suas ideias, principalmente, as anticlericais. Em alguns periódicos participou como colaborador, em outros, como redator e diretor/fundador. 
Entre os veículos em que publicava seus artigos de viés maçônico e esotérico, estão A Ideia (1889 -?), Galáxia (1897 -?), Myrto e Acácia (1916 - 1920), Phytagoras (19201927), Luz de Krotona (1921 - 1927), Jerusalém (1898 - 1902), A Esphynge (1899 1906), Ramo de Acácia (1908 - 1912).

Dario Vellozo também pensou e escreveu sobre a educação e sobre a escola brasileiras, assim como refletiu sobre a sociologia, com trabalhos publicados nas revistas Pátria e Lar (1912-1913) e Brasil Cívico (1918).

Em 1902, publicou o livro Lições de História; em 1904 a obra No sólio do Amanhã, de viés anticlerical; em 1905, o livro Voltaire, no qual tece críticas à Igreja Católica. Em 1906, veio a lume a revista $A$ Escola, fundada pelo Grêmio dos professores do Ginásio Paranaense e da Escola Normal, onde Vellozo expôs vários de seus projetos pedagógicos e, um ano depois, em 1907, publicou o livro Compêndio de Pedagogia. Com o intuito de colocar em prática suas ideias educacionais, Vellozo criou em 1914, na cidade de Rio Negro (PR), a Escola Brazil-Cívico, que tinha como base os pressupostos teóricos que defendia, enfatizando uma educação que incluía esportes, agricultura, humanidades e iniciação científica.

Além de toda a produção escrita, Dario Vellozo, em 1909, fundou o Instituto Neo-Pitagórico (INP), que tinha, como uma das metas, "realizar a fraternidade pitagórica" (VELLOZO, 1969, vol. 1, p. 38). Segundo a página atual do INP que está disponível na internet, ${ }^{2}$ "O Instituto Neo-Pitagórico é frateria destinada ao estudo, ao desenvolvimento das faculdades superiores do Ser, ao altruísmo, inspirado nos Versos de Ouro de Pitágoras, para a Cultura, para a Verdade, para a Justiça, para a Liberdade, para a Paz, para a Fraternidade e para a Harmonia". O INP tem como princípios fundamentais: "A Amizade - por base. O Estudo - por norma. O Altruísmo - por fim" (VELLOZO, 1969, volume 1, p. 47), frase que não pode deixar de lembrar os princípios positivistas de Comte: "O Amor por princípio; a Ordem por base; o Progresso por fim".

As bases fundamentais do INP são: I - Rebuscar as normas da Harmonia Cósmica. II - Realizar a Arte (Idealismo); e a Ciência (Verdade); desvendar o Mistério. III - Respeito mútuo - Liberdade absoluta - Fraternidade incorruptível (VELLOZO,

2 http://www.pitagorico.org.br/ 
1969, volume 1, p. 51-53). Dario Vellozo sublinha também a importância do estudo histórico, filosófico e social e, para tanto, os iniciados deveriam "banhar-se na luz desses faróis: Lisis, Timeu, Arquitas, Filolaus, Sócrates, Platão, Xenócrates, Apolônio de Tiana, Hierocles, Plotino, Próclus, Pico della Mirandola, Giordano Bruno, Leibniz, Court de Gebelin, Fabre d'Olivet, Victor Cousin, Fourier, Augusto Comte, Chaignet, Blavatsky, Saint-Yves d'Alveydre, Hoefer, Flammarion, Roso de Luna" (VELLOZO, 1969, volume 1, p. 50). Entre filósofos platônicos e neoplatônicos, astrônomos, matemáticos, ocultistas, esotéricos, Dario Vellozo, não aleatoriamente, encaixa Auguste Comte, fato que explicita um Dario Vellozo ao mesmo tempo defensor do Positivismo e estudioso do esoterismo; ocultista e protetor da moral que, de acordo com ele, por ser "pitagórica", é "elevadíssima" e decorrente dos Versos Dourados (VELLOZO, 1969, volume 1, p. 52). Estes são, em verdade, um guia de como agir em sociedade e fora dela, isto é, são leis que regem a vida pública e a vida privada, tal qual Comte também endossou; em suma, trata-se, segundo Vellozo, da "Síntese da Moral na Humanidade" (Idem). Seu fundador deixa claro que o INP busca, através de uma aproximação de escolas, de doutrinas e de indivíduos, a UNIDADE essencial do Cosmos: "acima de todas as divergências, fraternalmente, elucidando antagonismos, bem mais aparentes que substanciais, oriundos de pontos de vista particulares, de limitados graus de consciência, passíveis de Harmonia (Idem).

Outro ponto que coincide com o Positivismo de Comte é o enaltecimento dos "Grandes Vultos da Humanidade" como guias simbólicos dos Pitagóricos, que, como admite Vellozo, devem ser tomados como modelo, deve-se, então, agir de acordo com suas "nobres lições filantrópicas e instrutivo exemplo" (VELLOZO, 1969, volume 1, p. 53). Esses "Vultos da Humanidade" são reverenciados na Religião da Humanidade de Auguste Comte: nela se presta homenagem à Humanidade, compreendida como 0 conjunto dos homens vivos e mortos. Seu culto reverencia os antepassados, em prática ritualizada que tem por finalidade fortalecer o laço social entre os homens, a solidariedade entre as gerações e a transmissão do conhecimento. Tal prática também garantiria a continuidade da História, compreendida como um processo estimulado pelo aperfeiçoamento do conhecimento e orientado para o progresso. Em seu calendário, a Religião da Humanidade celebra homens e mulheres que contribuíram 
para fortalecer os valores e impulsionar a história da civilização Ocidental. A Humanidade é representada por uma mulher com os traços de Clotilde de Vaux, com uma criança no colo, símbolo da continuidade entre as gerações.

Também a moral é um dos tópicos de destaque sobre que o instituto Neopitagórico é fundado. Vellozo, que corrobora assim o pensamento de Comte sobre o progresso da Humanidade, naquele momento vê o coletivo desta forma:

O homem atual vive para si, para o prazer fácil, para o vício, para o álcool, para o fumo, para o jogo. Tem ambição que o obseda: gozar, mesmo à custa do roubo, da calúnia, da miséria, da honra das famílias, da tranquilidade dos lares; realizar o desejo abjeto, o ímpeto dos baixos instintos. O homem escravizou-se à animalidade; toda sua moral repousa em único aforismo, cínico e duro: Quem vier atrás, feche a porta (1969, volume I, p. 38).

Portanto, é também a moral que está entre os requisitos principais para pensar uma nova Humanidade que se inicia com a fundação do INP, pois, de acordo com Dario Vellozo, "não se vive para si o Iniciado, mas para outrem" (1969, volume I, p. 39). Pensando, então, no modo de vida social defendida pelo Instituto Neo-Pitagórico, é nessa referência a "outrem" que aparece mais outro ponto de contato do pensamento dos pitagóricos e, portanto, de Dario Vellozo com o de Auguste Comte, que expressa, como uma de suas máximas, a necessidade de "viver para outrem".

Além desses tópicos coincidentes com as ideias positivistas de Comte, também vale sublinhar a construção do próprio Templo das Musas ${ }^{3}$ que Dario Vellozo descreve como:

Construindo o Templo das Musas, singelo embora, tornando-o sede do instituto Neo-Pitagórico, almejo foi dos Amigos, graças ao altruísmo de digníssimos e honestas Pessoas, criar foco de irradiação de pensamentos e sentimentos louváveis, e de atos e ações meritórias, a bem de todos os seres. Único em todo o Ocidente, quiçá em todo o Orbe, - coube ao Paraná erguêlo em América, - inspirado em nobre almejo de Congraçamento, de Fraternidade, de Harmonia, de Paz (...) para o respeito à Consciência e à Liberdade, para a Ordem, o Progresso e a Estabilidade comuns, átomos que somos da Terra, sujeitos aos mesmos Destinos, flutuando na Imensidade, num átomo do Infinito (1969, volume 1, p.137 - grifo meu).

\footnotetext{
${ }^{3}$ Edificação onde funciona o INP.
} 
Fica explicitado na afirmação acima que Vellozo coloca nesse seu templo diferentes influências filosóficas, políticas, religiosas e literárias. A Ordem e o Progresso, instâncias tão caras aos positivistas, funcionam como dois pilares do Templo das Musas. Temos aí mais outro tópico em consonância com os ideais de Comte, este bastante conhecido até mesmo entre não especialistas.

Para além dessas compatibilidades, igualmente importante é a maneira como os iniciados do neo-pitagorismo veem a arte: "A arte é o esplendor do verdadeiro. A obra de Arte realiza o Belo, desabrocha nas almas os sentimentos superiores, a esperança, o altruísmo, o conforto" (VELLOZO, 1969, volume 1, p. 56). Essa afirmação é equivalente, mais uma vez, às ideias de Comte sobre a arte: esta visava a encantar e a elevar a vida humana, a trazer melhoras morais, a fortalecer nossas simpatias e desenvolver nossos nobres sentimentos. Para Vellozo, o Belo seria o "esplendor do Verdadeiro", representado por uma "arte que age pela emoção; cujo domínio é o Belo, a perfeição moral através dos sentimentos superiores". Em resumo, as ideias do poeta de Curitiba são tão semelhantes às de Comte que parecem ter sido copiadas.

Dario Vellozo, quando escreve sobre o neo-pitagorismo e a religião, a admite como o "elo da Fraternidade" e cita Herbert Spencer e Farias Brito:

Decorrente a lição de Herbert Spencer: Nossa tolerância deveria ser a máxima possível, ou antes, devíamos tender para algo melhor que a tolerância, tal como a entendem. Em falando das crenças alheias, devemos não só buscar não cometer injustiça em palavras e atos, como fazer-lhes justiça, reconhecendo-lhes francamente o valor positivo. Devemos atenuar e dissentir pela simpatia. [...] A religião, a meu ver, - escreve Farias Brito - pode ser definida nestes termos: é a moral organizada. $E$ isto quer dizer: é a sociedade organizada pela lei moral, é a sociedade governada pela razão (VELLOZO, 1969, volume 1, p. 61-62).

Assim, há muitas conexões na obra de Vellozo com o Positivismo de Comte. Ao atribuir uma influência da Escola de Crótona sobre a obra de Comte, talvez ele, Vellozo, tente justificar a presença do Positivismo em grande parte da sua produção escrita. Na página 92 do mesmo volume 1, acima citado, ele escreve que Comte "impregnou-se das doutrinas da Escola de Crótona (Escola Pitagórica), em mais de uma página da Política Positiva, procurando render justiça ao valor de Pitágoras". Vellozo cita o filósofo francês - "a sabedoria final institui a sinergia em síntese fundada 
na simpatia, concebendo toda atividade dirigida pelo amor para uma HARMONIA UNIVERSAL" - e admite que esse enunciado é "genuinamente pitagórico" e que grande parte das ideias comteanas são "luminosas" e se aproximam das concepções pitagóricas (VELLOZO, 1969, volume 1, p. 92). Por isso reconhece Vellozo que a "coordenação positivista" oferece valiosos elementos à "Síntese neo-pitagórica" e que esta terá um enriquecimento efetivo de um contingente "neo-espiritualista" a partir de estudos esotéricos, ocultistas ou teosóficos, ressaltando, portanto, a união da razão com o espírito (idem), o que constitui o ponto crucial de toda a produção escrita, sobretudo da poética do fundador do INP. Ao que tudo indica, as influências ocultistas, o simbolismo, o positivismo, o evolucionismo e a forte crença no progresso forneceram a Dario Vellozo argumentos que construíram um modo de pensar eclético, em que as ideias não entravam em confronto, mas sim se complementavam.

Abaixo segue uma página da revista Esphynge (1901, p. 8) com uma tabela que mostra claramente uma tentativa de transposição dos principais ideais positivistas, mas deslocados para um Positivismo ocultista, um Positivismo neo-budista e, por fim, um Positivismo espírita:

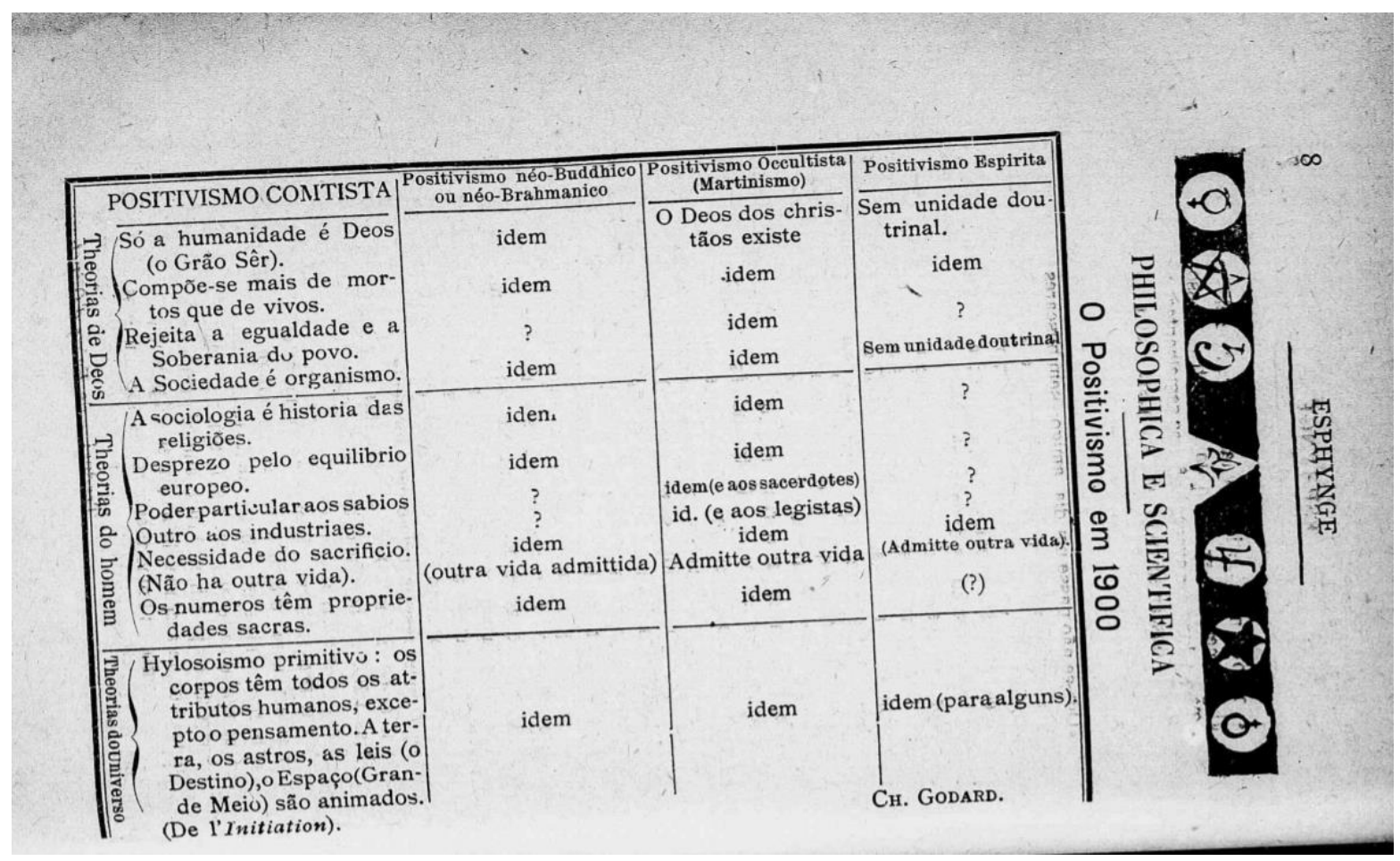


Com base nessa tabela, é perceptível a intenção de se fazer uma equivalência dos conceitos do Positivismo de Comte com os demais positivismos elencados. Nela se constata que todos os Positivismos admitem um Deus, seja ele a humanidade ou não, com exceção do Positivismo Espírita; também isso acontece com a noção de sociedade e todos os Positivismos da tabela admitem uma composição "maior de mortos do que de vivos", no tocante às "Teorias de Deus". Essa tabela, aliada ao pensamento de Vellozo, parece apontar para uma crença na evolução sobretudo espiritual. Ela indica que Vellozo articulava as ideias evolucionistas científicas à ideia de um processo de evolução espiritual, e essa levaria a humanidade à perfeição:

\begin{abstract}
A espiral é o símbolo da Evolução, o caminho da Perpectibilidade... [...] A Vida é espiral: as sociedades, as civilizações, as raças, as espécies - não avançam ou recuam descrevendo circunferências. A subida é espiral, espiral a queda. Os ciclos manvantáricos são curvas espiralantes. Não passa o mesmo astro duas vezes em mesmo ponto do espaço; nem repassa o Homem os pontos do trâmite percorrido... Não há duas sensações perfeitamente iguais, nem impressão ou emoção que se reproduza. O momento vivido está perdido... Só o sonho, a Cisma, a Reminiscência evocam os édens e os infernos (VELLOZO, 1969, volume I, p. 339-340).
\end{abstract}

Sobre as "Teorias do homem", ainda com base naquela tabela, todos os Positivismos creem em uma "necessidade de sacrifício", mas apenas o Positivismo Comtista não admite outra vida. E sobre o Universo, todos os Positivismos são tidos como Hilozoístas, isto é, eles admitem que a natureza não é algo inanimado, não é estática. Ela tem vida e não é desprovida de movimento. O Hilozoísmo, então, considera que exista alguma espécie de animação na matéria, inclusive sensibilidade e espontaneidade nas atuações e nas respostas. Mais especificamente, sobre 0 Hilozoísmo, Abbagnano escreve que se trata de:

Crença ou doutrina segundo a qual a matéria vive por si mesma, ou seja, possui originariamente animação, movimento, sensibilidade ou qualquer grau de consciência. Essa doutrina não equivale à negação da matéria e à sua resolução em forças ou elementos espirituais; ao contrário, costuma ser uma expressão do materialismo, doutrina que reconhece a matéria como única realidade. [...] O Hilozoísmo antigo foi retomado pela filosofia da natureza e pela magia do Renascimento. [...]. Essa doutrina é repetida nos mesmos termos por Campanella e por Giordano Bruno [...]. O Hilozoísmo é, pois, o pressuposto da magia, com tentativa direta para dominar as forças animadas da natureza através dos encantos (2007, p. 581). 
Parece ser a partir do Hilozoísmo - e não somente dele -, inscrito na tabela acima, que podemos já vislumbrar um inusitado e possível diálogo entre o Positivismo e o Esoterismo, o que é tão importante na discussão da obra de Dario Vellozo e de muitos outros seus contemporâneos. Se acreditarmos, como nos diz Abbagnano, no Hilozoísmo como uma expressão do materialismo que reconhece a matéria como única realidade e, ao mesmo tempo, a concebermos, tal qual Giordano Bruno a utilizou, isto é, como o pressuposto da magia que tentava dominar as forças animadas da natureza, temos aqui duas importantes concepções: a primeira seria o materialismo como uma unidade do Positivismo; e, a segunda, a dominação das forças da natureza como um dos pressupostos do Esoterismo. Essa constatação nos faz perceber, entre outras coisas, que Dario Vellozo, ao mesmo tempo em que dirigia grupos esotéricos e simbolistas, de caráter secreto e iniciático, atuava também como defensor do Positivismo, do evolucionismo, constituindo, ele próprio uma espécie de mosaico.

Voltando, pois, à produção do poeta, no ano de 1923, Dario Vellozo se tornou diretor da coluna Dórica, no jornal Gazeta do Povo (BEGA, 2013). Nessa coluna, além de artigos de sua autoria, também eram publicados escritos de membros do INP. No ano de 1932, ele se aposentou do magistério e, no ano seguinte, publicou a obra Atlântida, que parece ser um balanço de suas lutas e de seus sonhos. Em 1936, publicou, então, sua última obra, Jesus Pitagórico, um diálogo entre as figuras de Jesus e do próprio Vellozo, em que o autor é quem recebe ensinamentos.

Finalmente, quanto a suas publicações literárias, especificamente a produção poética, elas estão presentes sobretudo nas revistas: O Cenáculo (1895-1897) e Revista Azul (1891-1893). Aquela foi fundada por Dario Vellozo em parceria com Silveira Netto, Júlio Pernetta e Antônio Braga; esta foi criada em conjunto com Júlio Pernetta e Leôncio Correia, em 1893, e era direcionada às leitoras.

Aproximadamente em 1899, Dario Vellozo entrou em contato com H. Girgois, supremo delegado para a América do Sul, do Grupo Independente de Estudos Esotéricos, de Paris, criado e dirigido por Papus. Segundo Maria Tarsila Bega, por volta dessa mesma época também Dario Vellozo ingressa na Association Alchimique 
de France, tendo como Grande-Secretário Jollivet-Castelot (2013, p. 236). Em maio de 1900, o poeta curitibano fundou o Grupo Independente de Estudos Esotéricos "Luz Invisível". No regulamento desse grupo descreveu assim a sua intenção: era uma congregação destinada a promover, por meio de conferências, leituras, palestras e sessões práticas, discussões de questões relevantes sobre ciência oculta, magnetismo, hipnotismo e literatura esotérica. Também, na regulamentação do grupo, constava que havia um embasamento nos Estatutos Gerais do próprio Grupo Martinista de Papus, em Paris. Com isso e após carta de autorização para a fundação do grupo, em 10/07/1900, nascia o primeiro grupo esotérico Martinista do Brasil.

A esse respeito, vale a pena atentar a um soneto de Vellozo - dedicado a Júlio Pernetta, Silveira Netto e Antônio Braga, amigos escudeiros - do ano de 1898, isto é, da mesma época em que o seu esoterismo ficou explicitamente patente:

\author{
FLOR SIMBÓLICA \\ Esfinge, ao luar, cismando. Em que é que cisma a Esfinge? \\ Isis, no céu, fulgura, entre os lírios de Amon... \\ E o luar brilha; e o luar dorme; e o luar cinge \\ Nilo que vai rolando a barca de Caron. \\ Barca de Isis, no Azul, bari de argentum! Astro! \\ O mistério do Além brilha nas tuas ondas! \\ Vogas! Amon rutila em templos de alabastro... \\ Vogas! E o Infinito as hipogeias sondas... \\ Diadema de luz a tua fronte aureola; \\ Osíris brilha, Osíris sonha em teu seio de pérola! ... \\ E a Esfinge dorme; e o Luar Brilha; e o Nilo sonha. \\ Dorme! Esfinge do amor no seu sudário eterno! \\ Brilha! Flor imortal, flor de Amon! Brilha e sonha, \\ Isis! Lótus do Além! - Isis, flor do Mistério!
}

(VELLOZO, Esotéricas [21/07/1898], 1969, volume 3, p. 87)

Era um esoterismo que perpassava toda a produção escrita do poeta, seja em verso seja em prosa. No caso do poema acima, temos imagens egípcias parecendo saídas de Alexandria, nos primeiros séculos da era cristã, quando o esoterismo ocidental se foi forjando. De outro lado, é curioso e muito interessante como suas ideias acabaram por constituir uma teia contraditória, pois, enquanto ele funda, 
escreve e dirige revistas de cunho explicitamente maçônicos, que, de modo sumário defendem um ideal racional, propagará com um viés alternativo, referindo-se à fundação do INP, "[...] uma frateria espiritual, em que pelo menos pudessem se afinizar cada vez mais aquelas belas almas, sedentas de Luz, a fim de que, embora separadas fisicamente pela distância, estivessem unidas pelo mesmo grande e nobre pensamento de verdade e justiça, que são as duas colunas da Ordem e do Progresso" (VELLOZO, 1969, volume I, p. 40). Em vista disso, Vellozo mistura o ideário positivista ao esotérico, e, de forma paradigmática admite que: "Um dos fins do INP é criar contracorrente à dissolução moral que avassala a sociedade contemporânea, formando células conscientes da sociedade futura. [...] O progresso é resultante da lucidez do espírito. Estuda, medita, analisa, sintetiza; faz-se mais e mais consciente, a fim de propagar os ideais de Verdade, Justiça, Liberdade, Amor, Paz" (VELLOZO, 1969, volume 1, p. 41).

\section{O Cenáculo}

Foi por volta de 1890 quando Vellozo reuniu em torno de si um pequeno grupo de jovens interessados em ler e discutir obras dos românticos Casimiro de Abreu, Castro Alves, Fagundes Varela, Álvares de Azevedo, entre outros. Mais tarde, as leituras voltaram-se para os escritores como Mallarmé, Baudelaire e Edgar Allan Poe. Os serões literários diários contribuíram para que o pequeno grupo constituísse uma associação - batizada de Cenáculo. Sintomaticamente, a associação originou-se de um debate travado entre Vellozo e Antônio Braga, na biblioteca do Club Coritibano, sobre as poesias daquele primeiro. O grupo (que recebeu a alcunha de Grupo Cenáculo), acrescido de Silveira Neto e Lício de Carvalho, passaria boa parte dos anos seguintes lendo a obra uns dos outros, além das de Bilac, Zola, Bourget e Luís Murat e outros (PILOTTO, 1990, p. 96). Além disso, segundo confissão do próprio Vellozo:

Líamos e discutíamos: ideias anavalhantes, fabulosas empresas avultavam, explodiam, desmoronavam, num fragor de catadupas, num trágico estrugir de dinamites reivindicadoras. Rápidas, fugiam as horas, imperceptíveis, esfolhando empresas, esgarçando arminhos. Declamávamos Hugo e Murat, penetrávamos corajosamente Darwin, Haeckel, Letourneau, Comte, 
Spencer...Leconte de Lisle e Shakespeare usufruíam cultos particulares; através do Dante, amávamos Beatriz; através de Petrarca, beijávamos os cílios de Laura. Enquanto Silveira Netto, pudicamente, corria o Kama Sutra, impregnávamos dos Evangelhos. [...]. Já então, éramos pela falange dos deuses olímpicos, adversos à legião dos santos ultramontanos.... Queríamos o naturismo dos enlaces castos, não a hipocrisia das continências convencionais... (VELLOZO, 1969, volume I, p. 336-337).

De acordo com Maria Tarcisa Bega, as discussões entre os membros do Grupo Cenáculo e o contato regular com a obra de Luiz Murat, além de toda a gama de leituras assumidas pelo poeta, propiciaram mudanças no estilo de Dario Vellozo, percebidas se comparadas as poesias de Efêmeras (1890) com a prosa de Esquifes (1893) (2013, p. 225). Escreve, sobre isso, o próprio Vellozo:

Não foi tão somente o inimitável autor de Ondas e Sara137 que contribuiu para a feição artística da minha manière literária e orientação poética; Byron e Lamartine, Musset e Esproceda, aqueles com o D. Juan, o Child-Harold, o Giaour e Lara, as Harmonias, o Jocelyn e a Chute d'un Ange, estes com as suas Poésies e Obras poéticas, - já me haviam vibratilizado a lámure teorba da Emoção e do Sentimento [...] Olavo Bilac foi-me também grato e simpático. E não te rememoro aqui o Álvares de Azevedo, o Casimiro de Abreu, o Varella e o Castro Alves, primordiais agitadores de nossa imaginação juvenil. As Ondas, incontestavelmente, deram-me a definitiva; e, de então, sigo, linha reta, o trâmite que tive a felicidade de apontar um dia aos companheiros do Cenáculo, e vamos palmilhando resolutamente. Daí essa veneração pelo Shakespeare de Sara - em meu pensar, o genuíno criador do lirismo contemporâneo, no Brasil, - o primeiro poeta da América [...] (VELLOZO, revista do Club Coritibano, 1895, ano VI, n. 2).

Além das influências admitidas por Dario Vellozo, vale ressaltar as doutrinas ocultistas e teosóficas introduzidas no Paraná por João Itiberê, quando do seu regresso da Bélgica, em 1892 (BEGA, 2013, p. 226). De fato, elas se somaram para amalgamar o estilo do poeta, que ele próprio recordará na revista Ramo da Acácia, 15 anos mais tarde:

$\mathrm{O}$ aroma do Panteísmo atraia-me ao Oriente. Foi quando me deparou o n. 30 da Revue Encyclopedique Larousse e traduzi e entrei a publicar no Clube Coritibano (ano VII, n. 9, 15 de setembro de 1896) as primeiras notícias que me vinham de Teosofia e Ocultismo. Estudei Papus, Barlet, De Guaita, Sedir, Saint-Yves d'Alveydre, Fabre d'Ollivet, Court de Gébelin. [...] Há onze anos estudo a Teosofia, há quinze o Ocultismo; em ambos hei encontrado base idêntica à dos Antigos Mistérios, à Doutrina dos Colégios Iniciáticos, sintetizada na escola de Crótona, fundada por Pitágoras, e continuada até a época atual (VELLOZO, Ramo da Acácia, 1911, ano IV, n. 28). 
Sobre João Itiberê, que acabou se transformando em um guia intelectual e amigo, a quem Dario Vellozo dedicou vários trechos de sua obra, Andrade Muricy ressalta:

As doutrinas ocultistas, introduzidas no Paraná por João Itiberê da Cunha, tiveram em Dario Vellozo o seu mais apaixonado e dedicado prosélito. Os livros de Saint-Martin, Swedenborg, Péladan, Saint- Yves d'Alveydre, Papus, Stanislas de Guaita, Fabre d'Olivet, Jules Bois, Schuré; os poemas iniciáticos do Oriente; o wagnerismo ortodoxo; o esteticismo inicial de Huysmans; Dante Alighieri; a poesia simbolista e a de Luis Murat; o socialismo humanitarista, o anticlericalismo radical, apaixonado e proselítico, a filosofia grega: eis as fontes que contribuíram para formar sua personalidade, que um legítimo dom lírico harmonizava, num todo que tinha traços de grandeza, e sempre singular, e nunca vulgar ou tedioso (MURICY, 1987, volume I, p. 404).

Do positivismo ao ocultismo, da filosofia antiga à moderna, foram estes os temas principais a que Dario Vellozo se dedicou no início dos anos de 1890 e que forneceram instrumentos para uma modificação na sua produção (principalmente na sua poesia). Esse repertório é salientado por ele próprio no prefácio de Esquifes, publicada em 1896:

[...] agora que, levado para outro centro de ação, em que não há desferir seguidilhas e barcarolas, impossível se me torna salmodiar demoradamente as cândidas litanias sonhificadoras de místicos trovadores; - resolvi, em antes de para sempre abandonar o país das suavidades nostálgicas, reunir os raros fragmentos de uma esperança morta [...] que, como os primeiros Ensaios, resumem as singelas primícias de uma peregrina romaria literária [...] uma recordação, uma lembrança, atestando o extremo final da venturosa fase [...] (VELLOZO, 1969, volume II, p. 35).

É, sobretudo, a partir de tais debates e ideias que Dario Vellozo, Silveira Netto, Júlio Pernetta e Antonio Braga se uniram para inaugurar, em 1895, a revista $O$ Cenáculo, cujo dogma era "O Sentimento pelo sentimento" e tinha por divisa: "A moral - por princípio; A sinceridade - por norma; O aperfeiçoamento - por fim" (dogma e divisa que, mais uma vez, fazem referência explícita ao ideário positivista de Auguste Comte). De periodicidade mensal, $O$ Cenáculo teve mais de 30 números editados de 1895 a 1897. Embora intitulados como simbolistas, os próprios dirigentes da revista não se identificavam como partes de uma tendência única de escrita; sobre isso afirma 
Dario Vellozo, na apresentação da sua primeira edição:

[...]O Cenáculo não vem pugnar dogmaticamente por nenhuma escola filosófica ou literária, porquanto não admite o exclusivismo partidário, nem reza liturgicamente as litanias salmodiadas pelo fanatismo ortodoxo; quer 0 Sentimento pelo Sentimento e a Verdade pela Verdade: traz a enérgica abnegação heroica dos agitadores que reagem contra a inércia e apatia da ignorância perniciosa e sudarisadora, a boa vontade dos simples que lutam pertinazmente pela insigne vitória das justas causas magnânimas. Procurará, corajosamente, aproveitando os minérios, -heterogêneos embora, -que constituirão quiçá o período primordial da literatura paranaense, -concorrer também ao certame cientifico-literário que já se vai acentuando em alguns dos demais Estados da República (VELLOZO, revista O Cenáculo, tomo I, abril de 1895 , p. 5)

Em verdade, $O$ Cenáculo era um pot-pourri de pensamentos que se materializavam na escrita, contemplando tratados sobre a psicologia, sobre o evolucionismo, sobre o positivismo; crônicas anticlericais; poesia simbolista... enfim, era uma revista eclética no seu mais completo significado.

No fascículo 1, por exemplo, há o soneto "O Modelo", de Silveira Netto, com o uso de imagem bem parnasiana, a das estátuas em mármore. Seu título, em princípio, parece fazer remissão à própria poesia parnasiana, já que "modelo" poderia ser uma metáfora da "arte pela arte". Contudo, não é a estátua que indicaria esse modelo (ou seja, a forma perfeita), mas sim a mulher de carne e osso que guiou o escultor no trabalho formal; seus "olhares lúbricos e ardentes" acrescentam, assim, à temática do perfeccionismo formal, a sensualidade não mais lírica que marca os versos dos parnasianos:

Nua, de pé, a branca estátua encapa O povo que contempla os mais divinos E corretos contornos femininos Que traduzir o mármore sonhara.

Ao lado a moça, de olhos peregrinos, Que fora o magistral modelo para Essa obra d'arte sensual e rara.

O escultor inda observa os talhes finos.

E a moça, virgem, bela, -uma conquista, Goza todos os júbilos do artista, Ante $o$ aplauso dos mestres admirados; Mas o rubor lhe tinge as faces quentes 
Ao ver olhares lúbricos e ardentes

Ferindo os seus contornos cinzelados.

(NETTO, Silveira. O Cenáculo, 1895, p. 6).

Logo depois do soneto, talvez como um contraponto questionador sobre o tema da mulher, há um longo ensaio de 14 páginas que trata de psicologia, escrito por Justiniano de Mello e Silva, evidenciando a maneira como a natureza e a psicologia destinaram à mulher o papel de apoio da família e da sociedade, corroborando, portanto, a leitura positivista da mulher inserida na sociedade. E, assim escreve:

Augusto Comte, o oráculo e fundador da filosofia positiva, escreveu: Superiores pelo amor, mais bem-dispostas para sempre subordinarem ao Sentimento a Inteligência, as melhores constituem espontaneamente seres intermediários entre a Humanidade e os Homens. Tal é o seu sublime destino aos olhos da religião demonstrada. O Grande Ser confia-Ihes especialmente a sua providencia moral para entreter a cultura direta e contínua do afeto universal, no meio das tendências teóricas ou práticas que dele nos desviam incessantemente (MELLO e SILVA, O Cenáculo, 1895, p. 12)

À vista disso, é abundante o material em que se misturam temas científicos, como um longo artigo de Carvalho de Mendonça ${ }^{4}$ tratando da evolução do homem, da antiguidade até o final do século XIX, demonstrando, dentro de uma perspectiva evolucionista, os avanços da civilização ocidental nas artes, na literatura e na ciência.

Havia muitos poemas como aquele de Silveira Netto (exposto acima), fazendo críticas à estética parnasiana. Este de Antonio Braga é outro exemplo:

\author{
ANÁTEMA \\ Fiz, dos sonhos de amor ardente, o puro \\ Escrínio onde encerrava a imagem tua. \\ Eras a estátua branca e seminua \\ Da esperança, apontando-me o futuro. \\ Veio a procela: - o céu tornou-se escuro, \\ E de um corisco à chamejante pua, \\ Vacila estátua, move-se, recua... \\ Rola do pedestal imóvel, duro, \\ Hipócrita! Abateu-te a tempestade!
}

\footnotetext{
${ }^{4}$ Disponível nos fascículos 12 e 13 da revista O Cenáculo, de 1896.
} 
És feita unicamente de vaidade,

Foge de mim teu coração levando...

Expõe-no e vende a quem quiser possuí-lo,

Eu vejo ainda o pedestal tranquilo

Vejo a estátua pelo chão rolando. ${ }^{5}$

Antonio Braga, usando a metáfora da "estátua branca", imagem recorrente nesses poemas, enfatiza a frivolidade da "arte pela arte", que, frente à enxurrada de novas influências, inicialmente quer se submeter apenas a si mesma, mas que acaba por sucumbir ao ataque da adversidade: "Vejo a estátua pelo chão rolando". Aqui é uma tempestade que faz cair moralmente a amada; em "Profissão de fé" de Bilac, é o ataque dos opositores à forma pura parnasiana.

Além desses trabalhos, O Cenáculo publicou artigos sobre a questão indígena, tanto de Rocha Pombo quanto de Vellozo, cujo intuito era discutir o Nacional e a defesa dos caingangues, índios que estavam sendo dizimados no interior do Estado.

Foram produzidos e publicados, nesses três anos de $O$ Cenáculo, uma quantidade relevante de textos, principalmente, científicos e panfletários do anticlericalismo, do evolucionismo, do positivismo, sendo estas, em parte, as tônicas que impulsionavam a publicação de Dario Vellozo, sobretudo no que diz respeito à prosa. Contudo, a partir do início de 1897, quando começa o declínio da revista, por Vellozo se ver praticamente sozinho à frente dela, diminuem os debates anticlericais, voltando-se para uma publicação, em sua maior parte, de contos e de crônicas. Vellozo, que vislumbra o fim d'O Cenáculo, escreve no editorial de janeiro de 1897:

O Cenáculo continua, corajosamente, a tentativa encetada em 1895. Animamnos, ainda e sempre, os mesmos sentimentos, a mesma boa vontade, a mesma esperança e o mesmo anhelo dos rubros dias de estreia, quando, reunidos, -os quatro companheiros, - apresentávamos ao público o primeiro fascículo desta revista. Então, -como ainda hoje, - nos unia fecunda afinidade intelectual, -nosso mais poderoso estimulo, e o consolador conforto, quando, aos suaves crepúsculos das serenas tardes curitibanas, -cismávamosmuezins da Idea -consorciando pensamentos, consorciando almas, -em pleno pais do Ideal e do Sonho. Hoje, os muezins se afastaram, pela distância, - continuando, porém, aproximados pelo coração. -Silveira Netto lá naquela deliciosa terra de Guanabara, continua de ilustrar o nome e acrisolar o espírito, brilhantemente, -honrando sempre a terra de seu berço, o sempre amoroso desta nossa revista que ajudou a criar, e não esquece nunca; Antônio Braga,

${ }^{5}$ Disponível no tomo I de 1895, mês de abril. 
-em S. Paulo, -tem colaborado com galhardia o talento em alguns dos principais órgãos da imprensa paulista, seguindo gloriosamente a fulgida ViaLáctea da Arte, que sabe tão bem palmilhar - levando nas mãos de sacerdote impecável o austero ritual de nossa imaculada afeição ; Júlio Pernetta,conquanto habitando esta cidade, -não tem podido continuar de deleitar-nos o espirito com as litanias do seu estro.-Oxalá, para logo possa o Cenáculo continuar de receber em suas páginas a frase amiga de tão peregrina inteligência, e, bem assim, a dos dois outros sacerdotes,- glória e orgulho do CENÁCULO (O Cenáculo, ano III, tomo IV, janeiro de 1897, p. 5-6).

O Cenáculo se concretizou naquilo que o termo significa: uma grande ceia, num grande templo, onde todos podem falar e discutir os mais diferentes temas através das mais distintas abordagens, cujo propósito principal estava em compreender as mudanças que começavam a tomar conta do país.

Em vista do que foi aqui trazido e discutido, é lícito afirmar que Dario Vellozo foi um intelectual do seu tempo, ativo, que pensava criticamente e que expunha o seu pensamento em muitos periódicos. Influenciado por gama aberta de vertentes filosóficas e esotéricas, fundou, dirigiu e colaborou com muitos veículos de comunicação. Vellozo conseguiu, de modo como poucos o fizeram, compor uma riquíssima obra, cuja exploração mais meticulosa ainda se está por fazer, pois há muito o que pesquisar e questionar. Por fim, é importante frisar que a obra de Dario Vellozo, assim como a de muitos outros escritores da virada so século XIX para o XX, é de impossível definição ou enquadramento, ela não se fecha em si mesma, ao contrário, se abre num mosaico de vastas possibilidades de discussões.

\section{Referências}

ABBAGNANO, Nicola. Dicionário de filosofia. São Paulo: Martins Fontes, 2007.

BEGA, Maria Tarcisa Silva. Letras e política no Paraná: simbolistas e anticlericais na República Velha. Curitiba: Editora UFPR, 2013.

COMTE, Auguste. Curso de filosofia positiva; Discurso sobre o conjunto do Positivismo; Catecismo positivista; tradução José Arthur Giannotti e Miguel Lemos. São Paulo: Nova Cultural (Os pensadores), 1988.

PILOTTO, Valfrido. A estirpe apostolar de Dario Vellozo. Curitiba: Edição do autor, 1990. 
VELLOZO, Dario. Obras I. Curitiba: Instituto neo-pitagórico, 1969.

. Obras II. Curitiba: Instituto neo-pitagórico, 1969.

Obras III. Curitiba: Instituto neo-pitagórico, 1969. 